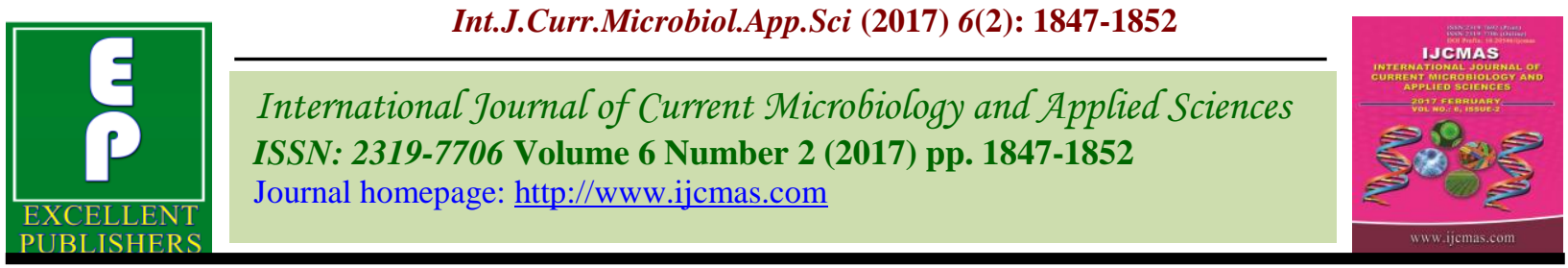

Original Research Article

http://dx.doi.org/10.20546/ijcmas.2017.602.208

\title{
Antifungal Activity of Wild Sage (Lantana camara) against Colletotrichum falcatum
}

\author{
A. Sreeramulu*, M. Arunakumari and P. Lakshmi Narasimha Reddy \\ Department of Botany, Sri Venkateswara University, Tirupati -517502, Andhra Pradesh, India \\ *Corresponding author:
}

\begin{tabular}{|c|c|}
\hline & A B S T R A C T \\
\hline $\begin{array}{l}\text { Colletorichum } \\
\text { falcatum, } \\
\text { Lantana camara, } \\
\text { Antifungal } \\
\text { activity }\end{array}$ & \multirow{3}{*}{$\begin{array}{l}\text { This study was conducted to evaluate the effect of crude and different solvent } \\
\text { extract of Leaf of Lantana camara, an aggressive invasive weed against plant } \\
\text { pathogenic fungi Colletorichum falcatum causing Red rot of sugarcane disease } \\
\text { under in vitro conditions. Aqueous crude extract and solvent extracts such as } \\
\text { extracts Methanol, Ethyl acetate, Chloroform were tested at } 2 \mathrm{mg} / \mathrm{mL}, 4 \mathrm{mg} / \mathrm{mL} \text { and } \\
8 \mathrm{mg} / \mathrm{mL} \text { concentrations. Results revealed that all the } 3 \text { solvent extracts showed } \\
\text { significant inhibition at higher concentrations when compared to the Standard } \\
\text { Fluconazole }(15 \mu \mathrm{g} / \mathrm{ml}) \text {. It was concluded that the selected crude and solvent } \\
\text { extract of Leaf of Lantana camara possesses antifungal activity against } \\
\text { pathogenic Colletotrichum falcatum and can be exploited as natural fungi toxicant } \\
\text { to control Red rot disease and thus reduce the dependence of synthetic fungicide } \\
\text { upto some extent. }\end{array}$} \\
\hline Article Info & \\
\hline $\begin{array}{l}\text { Accepted: } \\
\text { 15 December } 2017 \\
\text { Available Online: } \\
10 \text { February } 2017\end{array}$ & \\
\hline
\end{tabular}

\section{Introduction}

Fungal diseases have a serious effect on the growth and yield of crops. Therefore, conventional fungicides have been widely used. Fungicides have been considered to act directly against fungi, as well as induce a defence response in plant. The same mode of action has also been presumed for plant extracts against fungal pathogens. Plant extracts have been used for the treatment of plant diseases caused by pathogenic microbes since the 1990s (Wang et al., 2016).

Red rot is one of the most wide spread sugarcane diseases in the country and has been a constraint on sugarcane productivity (Saxena et al., 2013). Colletotrichum falcatum, the cause of red rot of sugarcane belongs to the Glomerallaceae of the Ascomycota (Sangdit et al., 2014 and Cannon et al.,2012). Sharma and Tamta (2015) summarized the distribution, mode and source of infection, description of casual pathogen and disease management of Red Rot which is known as Cancer of Sugar Cane.

The increasing demand of production and regulations on the use of agrochemicals and the emergence of pathogens resistant to the products employed, justifies the search for novel active molecules and new control strategies. It was believed that maiden work on the subject is vital to pursuit for naturallyoccurring antifungal elements and for 
auxiliary chemical and therapeutic research. Invasive weed Lantana camara $\mathrm{L}$. of family Verbenaceae is known for its vigorous growth with high fecundity and aggressive dominance, this weed threatens biodiversity so as a small solution to the problem, Lantana camara leaves were tested for its antifungal potentials and in search of finding a result to trace the natural fungal agent which can be used against Red Rot of Sugar cane caused by Colletotrichum falcatum.

\section{Taxonomic Description}

Lantana camara L., Sp. Pl. 627.1757.

Citation: Hook. f., Fl. Brit. India 4: 562. 1885; Gamble, Fl. Pres. Madras 1087(761).1924.

Habitat : Introduced as ornamental plant and now naturalised as weed in India.

Lantana camara is highly distributed and widely naturalised in Chittoor District and became invasive (Madhava chetty, 2015).

A survey of literature reveals that there are many plants and different extracts which possess antifungal activity. Even though there is need for the potent antifungal agents to control the fungal plant pathogens. This study aims at the assessment of antifungal treatment which commonly grown plant species throughout India to encounter the effect of the Colletotrichum species. However, their activity for fungal control in commercial industrial crops has not been determined.

\section{Materials and Methods}

\section{Preparation of the extracts}

Fresh plant leaf sample of Lantana camara were collected from Horsley Hills and some sites around Tirupati. Air dried at room temperature, powdered, divided into four portions and extracted using water and organic solvents (Methanol,ethyl acetate and chloroform)according to standard extraction method developed by Harborne (1998) and modified method of Nath et al., (2013)Firstly, 20 gof powdered plant sample was mixed thoroughly with the appropriate amount of solvent, left to stand for 24hours, and decanted. Then the liquid portions were filtered using a Buchner funnel. Filtrates from organic solvents were concentrated in vacuo using a rotary evaporator at temperature $40^{\circ} \mathrm{C}$. Finally, all the residues from water extracts were freeze dried. The extractive yields were evaluated according to Mitta et al., (2014). The dry extracts were stored in vials and refrigerated at $4{ }^{\circ} \mathrm{C}$ prior to antifungal test.

\section{Collection, isolation and maintenance of} the isolates

Identification of the isolates was based on the morphological descriptions of Colletotrichum falcatum species outlined by Mordue (1971) and Sutton (1992).Acquisition of two Isolates viz; SRM/Cf-01-15 and SRM/Cf-02-16 were isolated from the red rot infected stalks of different sites in Piler and Palamner region of Chittoor District, Andhra Pradesh. Cross checked with the Mycobank Accession: Colletotrichum falcatum Went, Archief voor de Java Suikerindustrie 1: 265 (1893) [MB\#157602].

The collected stalks were surface sterilized, and the infected parts of the internodal tissues were taken out with the help of a cork borer.

\section{Antifungal activity of plant extracts on the mycelial growth of test fungi}

Agar well diffusion method followed according to El-Khateeb et al., (2013). And Spectrophotometric assay according to Ahmed et al., (2012). Extracts were dissolved in Dimethyl sulphoxide (DMSO) 
and added to PDA medium immediately before it was poured into Petri dishes $(9 \mathrm{~cm}$ diameter) at $40-45^{\circ} \mathrm{C}$ to obtain a series of concentrations $(2,4$ and $8 \mathrm{mg} / \mathrm{mL})$. Control plates were treated with DMSO alone, and three replicates per treatment were used. Plates were incubated at $25 \pm 2{ }^{\circ} \mathrm{C}$. Colony growth diameter was measured after the fungal growth in the control treatment had completely covered Petri dishes (El-Khateeb et al., 2013).

A blank well impregnated with Dimethyl sulphoxide $\left(\mathrm{DMSO}_{4}\right)$ and Distilled water was used as negative control and Fluconazole $(15 \mu \mathrm{g} / \mathrm{ml})$ as positive control. The plates were then incubated at $37^{\circ} \mathrm{C}$ for $24 \mathrm{hrs}$. The antifungal activity was assessed by measuring the zone of inhibition. The relative antifungal activity of the extract was calculated by comparing its zone of inhibition with the standard drugs (Karthikeyan et al.,2016). Pathological assay was done according to the plug method according to the methodology followed by Saxena et al.,(2013).

The suspensions were adjusted by spectrophotometric method, adding saline solution, to reach the value of 0.5 in the McFarland scale corresponding to a final concentration of $3.0 \pm 2.0 \times 10^{6}$ cells $/ \mathrm{mL}$.

Fungal colony diameter of treatments and control sets were measured and percentage of mycelial inhibition was calculated using the following formula:

Percentage of mycelial inhibition $=[\mathrm{C}-\mathrm{T} /$ $\mathrm{C}] \mathrm{x}$ 100. Where, $\mathrm{C}$ and $\mathrm{T}$ are the growth diameter $(\mathrm{mm})$ in control and treatment respectively. The minimum and maximum values were $0 \%$ and $100 \%$.The Minimum inhibitory concentration (MIC) and Minimal fungicidal concentrations (MFC) were estimated according to the methodology followed by Rachuonyo et al., (2016).

\section{Results and Discussion}

Crude plant extracts, posses a mixture of active and nonactive compounds, provide many advantages as antimicrobial agents. The first is their natural origin, which seems much safer for consumers and the environment; second, they are at low risk for resistance development of pathogenic fungi; third, they represent a rich source of potential bioactive compounds. As various modes of action exist in different extract, it is difficult for pathogens to develop resistance to such a mixture of components. Therefore, the development of management strategies to replace or supplement synthetic fungicides with natural bioactive products is desirable (Kosanic et al., 2016 and Wang et al., 2016). Hence, this study was conducted with objective of determining the in vitro effect of plant extracts on conidial germination, mycelial growth of Colletotrichum falcatum and their efficacy against the development of pre and postharvest Red Rot Disease.

Previously we have studied on Red strip, Red rot and Rust on Sugar cane leaf has been spotted out in Rayalaseema (Hare Kondaiah and Sreeramulu, 2014 a \& b). In continuation of the research on Sugar cane disease we focussed on the Red Rot caused by Colletotrichum falcatum.

Previous workers have done research on Antifungal activity and on Plant pathogenic fungi. El-Khateeb et al., (2013). evaluated the antifungal activity of leaf extracts of various plant species (Thompson seedless grape (Vitis vinifera cv. Sultana),flame seedless grape (Vitis vinifera cv. Roumy Ahmer), Zizyphus (Zizyphus spina-christi cv. Willd), Pomegranate (Punica granatum cv. Baladi) and Fig (Ficus carica cv. Sultani) against five plant pathogenic fungi viz. Alternaria solani, Botrytis cinerea, Botrytis fabae, Fusarium oxysporum and Fusarium 
solani under in vitro conditions with phytochemical screening and HPLC analysis. Manoorkar and Gachande (2014) evaluated antifungal activity of some medicinal plant extracts (Ocimum sanctum, Mentha arvensis, Cymbopogon citratus, Eucalayptus globulus, Tridax procumbens) against some storage seed borne fungi (Aspergillius niger, A. flavus, A. terreus, A. fumigatus, Pencillium citrinum, Fusarium oxysporum, Alternaria alternata, Curvularia lunata) of Groundnut.

\section{Extractive Yield (g)}

The Extractive yield for $20 \mathrm{gms}$ of the different extracts are given in Table-1. Methanolic extract showed highest Extractive yield (3.2g) and Ethyl acetate extract (1.8g) showed minimum yield

\section{Antifungal Activity}

Different extracts (Crude Aqueous, Methanolic, Ethyl acetate and chloroform) of Lantana camara leaf were investigated for their antifungal activity and minimum fungal concentrations (MFCs) against Colletotrichum falcatum.

A visual estimation of the growth and spore formation of the tested fungi species using a 0-10 scale (with the lower score being most effective) was used at 4,8 and 16 days after incubation. Since colony growth of the fungi was not a regular circle. The mean diameter (average of the longest and the shortest diameter of the same colony) was calculated and the fungi toxicity was recorded in terms Table 1 of percentage colony inhibition.

The solvent extracts differed significantly with regard to their susceptibility to plant extract. The Minimum inhibitory concentration (MIC) for crude aqueous extract was found to be less than minimum dose $(2 \mathrm{mg} / \mathrm{mL})$. But for other extracts (Methanol, Ethyl acetate and Chloroform) the MIC is found to be more than minimum dose.MIC is $4 \mathrm{mg} / \mathrm{mL}$ for Solvent extracts.

Minimal fungicidal concentrations (MFC) is 8 $\mathrm{mg} / \mathrm{mL}$ for Crude Aqueous extract. The percentage of Inhibition is higher at $8 \mathrm{mg} / \mathrm{mL}$ when compared with $2 \mathrm{mg} / \mathrm{mL}$ and $4 \mathrm{mg} / \mathrm{mL}$. MFC for solvent extracts is $2 \mathrm{mg} / \mathrm{mL}$.

When C.falcatum were treated with a low concentration of LCE, only indistinct growth inhibition occurred (Table 1). When LCE concentration was increased, the growth of C.falcatum was inhibited gradually, indicating that LCE inhibited the fungal growth in a dose-dependent manner. Increase in the concentrations of polar solvents LCE impaired both cell integrity and viability. The diameter of the fungi plaque growing on the control plate had reached up to $4.2 \pm 1.5 \mathrm{~cm}$ after a 36-hour culture, but no change took place on the treated plate.

Three of Four extracts were effective against the phytopathogenic fungi at lower dosage taken. Colletotrichum falcatum, extracts were strongly active and showed fungistatic and fungicidal activities against the phytopathogenic fungi with minimal inhibitory concentration. Some stimulated, others inhibited or had no effect.

Further work is needed to isolate and characterize the active agents and their mode of action, in addition to studies on economic and dosage of L.camara extract, its frequency and timing of application as a fungicide in the field or as natural preservatives. We recommend further research on pathogenic fungi against weeds, which greatly helps us to find biological control agents and the search for a natural substitute with antifungal activity has been encouraged. 
Table.1 Effect of leaves extract on mycelial growth of tested fungi Colletotrichum falcatum

\begin{tabular}{|l|c|l|l|l|l|l|l|}
\hline Extract & E.Y & \multicolumn{7}{|c|}{ Zone of Inhibition (\%) } & & \\
\cline { 3 - 8 } & $(\mathrm{g})$ & $2 \mathrm{mg} / \mathrm{mL}$ & $4 \mathrm{mg} / \mathrm{mL}$ & $8 \mathrm{mg} / \mathrm{mL}$ & Control & MIC & MFC \\
\hline Crude Aq. & 2.6 & $08 \pm 1.68$ & $14.04 \pm 1.29$ & $37.21 \pm 0.42$ & $90 \pm 0.00$ & $>2 \mathrm{mg} / \mathrm{mL}$ & $8 \mathrm{mg} / \mathrm{mL}$ \\
\hline Methanol & 3.2 & $18 \pm 0.21$ & $38.60 \pm 0.55$ & $72.50 \pm 1.71$ & $88 \pm 0.00$ & $<2 \mathrm{mg} / \mathrm{mL}$ & $2 \mathrm{mg} / \mathrm{mL}$ \\
\hline Ethyl acetate & 1.8 & $20 \pm 1.86$ & $35.25 \pm 0.49$ & $57.77 \pm 0.90$ & $87 \pm 0.00$ & $<2 \mathrm{mg} / \mathrm{mL}$ & $2 \mathrm{mg} / \mathrm{mL}$ \\
\hline Chloroform & 2.6 & $17 \pm 0.38$ & $37.21 \pm 0.72$ & $60.90 \pm 0.72$ & $92 \pm 0.00$ & $<2 \mathrm{mg} / \mathrm{mL}$ & $2 \mathrm{mg} / \mathrm{mL}$ \\
\hline
\end{tabular}

In conclusion, according to obtained resultsin this investigation at preliminary level, we suggest that invasive weed Lantana camara leaf has proved to be a highly active antifungal agent, which implies that L.camaracrude aqueous leaf extract at minimal dose and solvent extract at higher may be effective in the control of fungal pathogen colletortichum falcatum, and such natural products would represent a sustainable alternative to the use of synthetic fungicides. We also believe that extracts of plants belonging to weed community may give a strong alternate to the synthetic chemicals. Application in large scales in pre- and postharvest periods, could have considerable economic benefits.

\section{Acknowledgments}

The authors are thankful to the Department of Botany, Sri Venkateswara University, Tirupati for providing the necessary facilities.

\section{References}

Ahmed M, Djebli N, Aissat S, Meslem A, Bacha S (2012). The Influence of Botanical Origin and Physico-chemical Parameters on the Antifungal Activity of Algerian Honey. Journal of Plant Pathology \& Microbiology.3(5):132.

Cannon PF, Damm U, Johnston PR, Weir BS (2012). Colletotrichum - current status and future directions. Studies in Mycology.73(1):181-213.

El-Khateeb AY, Elsherbiny EA, Tadros LK, Ali SM, Hamed HB (2013). Phytochemical
Analysis and Antifungal Activity of Fruit Leaves Extracts on the Mycelial Growth of Fungal Plant Pathogens. Journal of Plant Pathology \& Microbiology. 4:199 Harborne JB. (1998) Phytochemical Methods: A Guide to Modern Techniques of Plant Analysis. Springer Science \& Business Media.

Hare Kondaiah R and Sreeramulu A (2014a). A Survey on Bacterial Diseases of crop and Non-crops of Cuddapah District, Andhra Pradesh, India. International Journal of Current Microbiology and Applied Sciences. 3(8): 1095-1100.

Hare kondaiah R and Sreeramulu A(2014b). Survey on fungal diseased Crops in Cuddapah district of Andhra Pradesh. Indian Journal of Fundamental and Applied Life Sciences.4 (1): 244-25

Karthikeyan R, Sai Koushik O, Kumar PV (2016). Isolation, Characterisation and Antifungal Activity of $\beta$-Lapachone from Tecomaria capensis (Thunb.) Spach Leaves. Medicinal \& Aromatic Plants. 5(3): 239.

Kosanic M, Rankovic B, Rancic A, Stanojkovic $\mathrm{T}$ (2016). Evaluation of metal concentration and antioxidant, antimicrobial, and anticancer potentials of two edible mushrooms Lactarius deliciosus and Macrolepiota procera. Journal of Food and Drug Analysis. 24(3):477-484.

Mitta MN, Sankara Rao M, Ramesh L and Madhava Chetty K. (2014). PhytoChemical Evaluation and Anti-oxidant potentiality of Cycas beddomei Dyer Male cone aqueous Extract. International Journal of Drug Development \& 
Research. 6 (2): 220-227.

Madhava Chetty K, Sivaji K, Tulasi Rao K. (2015). Flowering plants of Chittoor district, Student offset printers, Tirupati, 4:124-127.

Manoorkar VB and Gachande BD (2014). Evaluation of antifungal activity of some medicinal plant extracts against some storage seed -borne fungi of Groundnut. Science Research Reporter, 4(1): 67-70

Mordue JEM(1971). Colletotrichum gloeosporioides: CMI Descriptions of Pathogenic Fungi and Bacteria no. 315. Kew, UK: Commonwealth Mycological Institute.

Nath MM, Santosh $\mathrm{CH}$ and Madhava chetty K. (2013). Antioxidant activity and its correlation of different solvent extracts of male cones of Cycas beddome Dyer, endemic taxa to seshachalam biosphere reserve. International Journal of Pharma and Biosciences; 4(4):(B)1394-1403.

Rachuonyo HO, Kamau DN, Ogola PE, Arika WM, Wambani JR (2016). In vitro Antifungal activity of leaf extracts from Aloe secundiflora,Bulbine frutescens,
Vernonia lasiopus and Tagetes minuta against Candida albicans. Medicinal \& Aromatic Plants. 5(2): 229.

Sangdit P, Leksomboon C and Lertsrutaiyotin R (2014). Cultural, Morphological and Pathological Characterization of Colletotrichum falcatum Causing Red Rot Disease of Sugarcane in Thailand. Kasetsart Journal : Natural Scienc. 48 : $880-892$

Sharma R and Tamta S (2015). A Review on Red Rot: The "Cancer" of Sugarcane. Journal of Plant Pathology \& Microbiology. S1:003

Sutton BC(1992). The genus Glomerella and its anamorph Colletotrichum. In: Bailey JA, Jeger MJ, Eds. Colletotrichum: Biology, Pathology and Control. Wallingford, UK: CAB International, 1-26.

Wang S, Zheng Y, Xiang Fu, Li S, Yang G (2016). Antifungal activity of Momordica charantia seed extracts toward the pathogenic fungus Fusarium solani L. Journal of Food and Drug Analysis, 24 (4): $881-887$.

\section{How to cite this article:}

Sreeramulu, A., M. Arunakumari and Lakshmi Narasimha Reddy, P. 2017. Antifungal Activity of Wild Sage (Lantana camara) against Colletotrichum falcatum. Int.J.Curr.Microbiol.App.Sci. 6(2): 1847-1852. doi: http://dx.doi.org/10.20546/ijcmas.2017.602.208 